\title{
印象評価に基づく総合評価式の定式化について
}

\author{
増山英太郎 （拓殖大学）
}

How to Estimate the Integrated Value from Separate Image Factors

Eitaro Masuyama (Takushoku University)

1. はじめに

本研究は，筆者が印象工学ワークショップへの参加 を契機として考えついた，「好み」,「美しさ」，「おかし さ」,「やる気」などの, 現代の我々にとうて大切な「総 合評価」を, いくつかの基本イメージ, $\mathrm{x}_{1}, \mathrm{x}_{2}, \cdots$ $\mathrm{x}_{\mathrm{k}}$ の重みつき合計によって求める手法の紹介と, 二三 の適用例について述べたい。

2. 方法

総合評価を行おうと思っている対象のイメージを S D法によってとらえるために, 反対語の対を $30 \sim 40$ 尺 度集め, 被験者達にそれらによって 7 段階評価させ, 結 果を主成分分析 $\rightarrow$ バリマックス回転して, 主成分（基 本）軸の解釈を行う。このようにして得られる基本軸 が，何時でも殆ど同じに得られ（条件 1 ）, さらに各主
成分の信頼度（ $\alpha$ 係数）が充分高い（条件 2 ）と良い が，この 2 条件をともに满たすことは，今のところ大 変難しい。このうちの片方を満たすだけで, 先に進み, 実験を繰り返すことによって，より良い式へと改良し てゆくのが, 実情に合っていると思う。基本軸が得ら れたら，それら主成分得点 $\mathrm{x}_{1}, \mathrm{x}_{2}, \cdots \mathrm{x}_{\mathrm{k}}$ を独 立変数, 総合評価 $\mathrm{y}$ を従属変数とする重回帰式を計算 すればよい。その様にして計算された，総合評価を例 示すると, 外国映画の女優の好み $\mathrm{y}$ は, $\mathrm{y}=-.212 \mathrm{x}_{1}$ $+0.531 \mathrm{x}_{2}+0.307 \mathrm{x}_{3}+0.366 \mathrm{x}_{4}$ となった。わ がままでなく, 明るく, 上品で, 大人っぼい女優ほど, 好まれる，となった。この式の説明率 $\mathrm{R}^{2}$ は 0.555 だっ た。

$16 \mathrm{~F} 12$

\section{直観像に関する心理学的研究 (2)}

- 直観像㮆体験の有無と心像を用いた描画課題における難易度との関係 -

○嶌田 久美 (拓殖大学大学院工学研究科) 増山 英太郎 (拓殖大学工学部)

Relationship Between Eidetic Experience and Difficulty for Portrait with Mental Imagery Kumi Shimada (Grad. Sch. of Eng., Takushoku Univ.)

Eitaro Masuyama (Faculty of Eng., Takushoku Univ.)

直観像とは，過去に経験した視覚的な印象が，あた かも知覚の場合と同じように, 外部空間に定位されて 見えるイメージを言う。視覚的イメージの一つである が，直観像を持つ者（直観像素質者）は非常にまれで あるといわれている。これまでの研究から，直観像素 質者は，日常生活における視覚化傾向が高いこと，想 像や空想に対する没入傾向が高いという知見が得られ ている。これより，普段から視覚的イメージを使用す る機会が多い人は，直観像幸質を有する可能性が高い ことが予想される。そこで工業デザインを専攻する大 学生を対象に，直観像様体験の有無に関するアンケー 卜を実施し，現在および過去における直観像，あるい はそれに類似した体験状況について調査を行った。ま
た, 心に浮かぶ顔のイメージ（記憶心像）のみを用い て, 似顔絵を描かせる課題（正面および側面）を実施 し，描画に対する主観的難易度，側面の顔を描く際の， 顔イメージの心的回転に対する難易度などについて回 答させた。直観像様体験のある者，すなわち直観像素 質者である可能性の高い者は, そうでない者に比べ, 描 画や心的回転に対してさほど困難さを感じないことが 予想される。そこで, 直観像様体験の有無と, 描画課 題に対する主観的難易度の関保について分析を行った。 また, これらの描画作品について，他者による評価を 行い, 直観像様体験の有無と描画のうまさ（そっくり さ）の関保についても分析・考察した。 